\title{
Community Preparedness towards Dam Disaster: Disaster Risk Reduction (DRR) Program in Cameron Highlands
}

\author{
Rahsidi Sabri Muda, Mohd Ramzi Mohd Hussain, Izawati Tukiman, and Fatin Shahira Abdullah
}

\begin{abstract}
Dam disaster occurrences are an unexpected event that occurs suddenly without warning. It has become very alarming, resulting in a catastrophic break followed by a flood wave at high speed with considerable loss of life and catastrophic damages to infrastructure and the environment. Given these circumstances, the community preparedness for disaster risk reduction (DRR) is important to strengthen disaster response strategies. It helps the community to understand the situations to face disaster and interact with present conditions with efficient manners. The research aims to investigate the community awareness and preparedness and the effectiveness of the DRR program toward dam-related disaster. In this research, two dams in Cameron Highland have been selected as sites study: Sultan Abu Bakar (SAB) Hydroelectric Scheme and its vicinity in Lembah Bertam; and Susu Dam and its vicinity in Pos Telanok. The research utilised questionnaire surveys as a data collection method, where Statistical Package Software SPSS Version 25 was used to analyse data. The finding indicates that an integrated community-based program is an effective approach to increase people's preparedness for the disaster. The result can assist local agencies and dam owners in formulating strategies for future DRR programs. Identifying these pertinent factors enables a greater understanding of the community's preparedness for disaster risk reduction (DRR) in both dams of Cameron Highlands.
\end{abstract}

Index Terms-Community preparedness, disaster risk reduction, dam failure, Dam disaster.

\section{INTRODUCTION}

A natural disaster is an event caused by natural forces; meanwhile, a man-made disaster can be defined as an event caused by humans intentionally or unintentionally. Dam disaster is one of the man-made disastrous occurrences, and it unexpected event might occurs suddenly without warning, which seriously impacts people's lives that exceed their ability to survive. It has become very alarming, resulting in a catastrophic break followed by a flood wave at high speed with considerable loss of life and the eventual catastrophic damages to infrastructure and the environment. An immediate response to face disaster would minimise the number of deaths, expenses, and impacts on the community and environment [1]. Therefore, appropriate disaster risk

Manuscript received January 30, 2021; revised May 15, 2021. This work was supported in part by the Tenaga Nasional Berhad (TNB) under Collaboration Grant TNB (Research)-IIUM.

Rahsidi Sabri Muda and Fatin Shahira Abdullah are with TNB Research, Malaysia (e-mail: rashidism@gmail.com,ffaezynn@yahoo.com).

Mohd Ramzi Mohd Hussain is with International Islamic University Malaysia (IIUM), Malaysia (e-mail: ramzi@iium.edu.my, izawati@iium.edu.my).

Izawati Tukiman is with International Islamic University Malaysia (IIUM), Malaysia (e-mail: izawati@iium.edu.my). reduction (DRR) strategies must be carried out to improve community preparedness in facing future disasters [2]. Community preparedness is important in strengthening disaster response strategies, helping the community understand the real situations to face disaster, and interacting with present infrastructure, urban development, and socio-economic situations to distribute resources constructively and efficiently [3]. In shaping our community to become a resilient community, it is essential to educate the community on awareness and preparedness.

Furthermore, M. Rahsidi et al., [4] and W. Adiyoso [5] suggested that numerous approaches in DRR programs may increase community preparedness. In this situation, society should always be conscious and prepared for disaster while at the same time trusting in fate and knowing that catastrophe is not just a tragedy. Community participation and involvement in the DRR program, such as awareness programs and evacuation drill exercises, are very important in developing better community resilience to face disaster. It is a crucial role for the agencies to contribute in future planning and implementation of DRR, which can be used as part of the approach for community preparedness. Discovering an appropriate approach to promoting public participation in the DRR program is highly needed. Hence, the research aims to investigate the community awareness and preparedness and the effectiveness of the DRR program toward dam-related disaster. The research objectives are i) to investigate the factors influencing the awareness of the community towards dam-related disaster and ii) to assess the preparedness level of the affected community towards dam-related disaster.

\section{COMMUNity PREPAREDNESS TOWARDS DRD}

\section{A. Community Preparedness}

In general, the community was known as a people who live in a group with various characteristics connected by social relations, sharing experiences, and participating in group activities in some location [6]. Preparedness is defined as the activities that need to be implemented to build a quick reaction to minimise risks and impacts [7]. Community preparedness is defined as people aware of preparing, sustaining, and recovering from an incident, either in the short or long term, and communities' ability to prepare and withstand natural or human-made disasters [8]. This is supported by [9], which authors had mentioned that being prepared is the key to a community's capabilities to respond and recover from a disaster. Preparedness aims to improve people's ability to respond to a disaster's impacts, while prevention intends to lessen disaster risks. To be prepared, 
people must have adequate knowledge and skills to reduce a disaster's effect on a community [10].

UNISDR [11], [12] defined DRR as a strategy prepared by an authority, industry, organisation, or company setting goals and clear targets for disaster risk reduction following relevant activities to achieve those targets. DRR is a strategic approach to disaster risk identification, evaluation, and reduction to minimise life losses by natural hazards through a strategic mitigation plan. The best way to prepare for a disaster is to develop a clear action plan that can be in placed in community engagement activities [11], [12].

\section{B. Important of Community Preparedness}

According to [13], emergency preparedness is performed in the face of some apathy by other resistance. Authors had mentioned that people are apathetic for not worrying about their exposure to disasters, so either to resist disaster preparation, as it requires resources that can contribute to other community needs. Furthermore, D. Kyne et al., [8] has stated that emergency preparedness is crucial in minimising and reducing disaster-related negative impacts. Preparing for future disasters will improve the ability to cope better response with external shocks and return to normal after the disaster. Thus, community emergency preparedness is necessary to increase the level of preparedness of a community.

The disaster continues to occur during the year in every region of the world, whereas these occurrences are unpredictable by their nature, leaving little time to plan [14]. K. Johnson [14] also explained that community preparedness might lessen the anxieties, worries, and losses. In the event of disaster occurrences, individuals, families, and communities should know the right action to be taken during an emergency and seek cover and look after basic needs. C. Goyet et al., [15] stated that community preparedness aims to reduce the impact of disasters on vulnerable people and prepare the organisation to create a structured strategy to manage resources and time. It can save lives and resources after a crisis and help affected people to build back better. Thus, it is necessary to provide sufficient time for planning and preparedness to face the disaster.

\section{Element in Community Preparedness}

J. Sutton \& K. Tierney [16] and R. Patrisina et. al., [17] has listed preparedness elements, including experience, knowledge, emergency plan, and information and communication. Yenni et al., [18] has found that people's past experiences would make them more prepared and stay safe in facing flood disaster, they inherit knowledge to prepare from their parents. In the study, the author proved that practising an integrated community-based disaster management system would increase preparedness and minimise losses. S. Sadeka et al., [19] has conducted the study to investigate the crisis encounters in emergency preparedness of the Orang Asli community. The study's result has discovered that they experienced both optimistic and traumatic disaster experiences and lacking readiness in facing disaster. Therefore, a disaster preparedness program should be effectively promoted to enhance awareness among the Orang Asli community [19]
Knowledge of the community toward the threatened disaster is one of the elements that became concerning by disaster stakeholders to improve disaster preparedness. Lack of knowledge of how to act in preparation for disasters may impede people from taking preparatory measures [20]. The scholars have addressed that knowledge sharing among community groups through community empowerment strategies would enhance people's confidence to face disaster. According to R. Patrisina et. al., [17], affected people should understand the hazards and risks they will face, and they have to understand the importance of preparedness to keep safe during the disaster. Additionally, Yenni et. al., [18] suggests that to sustain local knowledge and people preparedness, there is a need for emergency training and early warning knowledge to improve an emergency plan and making a proactive action.

Emergency preparedness is a vital part of work for first responders [21]. They will be dealing with people in challenging times of their duty during the catastrophic event [22]. A study by A. D. Setyawati et al., [22] suggest that continuing disaster drills training and implementing a formal disaster educational program to increase people preparedness [22]. Since 1996, Iran, through the International Institute of Earthquake Engineering and Seismology (IIEES) has started the "Earthquake and Safety" schools' program to promote "Safe Schools-Resilient Communities." In 2015, this program was expanded throughout the community to encourage public participation in disaster management at local levels [23]. This program helps to enhance emergency response and provide basic requirements for self-protection and evacuation to face disaster. The author also has mentioned that community participation in CBDRM activities is necessary to increase the people's preparedness in facing disaster. According to C. Guo et al., [3], community-based programmed should consider improving perceived community resilience by making more information-seeking channels available for residents.

\section{Community Preparedness toward Dam Disaster}

Dam disaster can be described as a catastrophic failure characterised by a sudden structural collapse of the dam structure, a sudden and unpredictable release of impounds of water, or the probability of such uncontrolled release [24]. According to [25], dams' failure can be due to overtopping, foundation defects, seepage, and piping. Floods occurring from dam failures may lead to catastrophic disasters with an enormous loss of life and damage, especially in dense urban areas [26], [27]. Dam failures have often occurred in the past, including the Vajont Dam's failure in 1963 in Italy caused 2600 deaths. The Teton Dam's failure in 1976 in America caused a hundred deaths and a financial loss of around \$1 billion. The failure of the Gouhou dam in 1993 in China caused 300 deaths [25]. The worst-case in history, the collapse of Banqiao Dam in Henan Province, China, due to Typhoon Nina in 1975 has caused 230,000 died [28]. In a recent failure of Saddle Dam D, Xe Pian Dam in Laos has left more than 6,600 homeless. As reported by Mike Ives [29], warning seemed too late and inadequate to alert people for their safety had caused at least 27 people to die. 


\section{E. Lembah Bertam Incident}

Disasters disrupt hundreds of thousands of lives every year. Any disaster has long-lasting effects, including both people and property. Lembah Bertam incident in October 2013 cost four lives, nearly 100 houses were destroyed, and more than 100 vehicles were heavily flooded in the downstream communities due to sudden water released from the dam [30]. Lack of preparedness among the community and the authorities was identified as one weakness in emergency response during the incident [31]. According to [31], there was no preparation for the flood disaster and no warning system at the local level during the event. There has been a little warning from sirens in the dam area. However, this warning was failed to relay the emergency message to local communities due to a lack of ability to understand the siren signal sound. After this incident, the dam owner and local agencies have taken immediate action by installing a sirens system in the downstream area. Community engagement and evacuation drills have been conducted with local communities and agencies to face such incidents in the future.

Unfortunately, in November 2014, once again heavy rainfall during the monsoon caused the reservoir water level to rise drastically. The dam owner had activated their standard operating procedure (SOP) by released water through the dam's operating gates when the water level in the reservoir rises unusually to avoid uncontrolled spillage from the dam. Fortunately, during this event, the community was alarmed by the siren system; no injuries and fatal cases were reported [26], [31]. According to N. Yahya et al., [32], siren systems are just tools, but what most important is the knowledge about how to take immediate action to save lives and avoid injury. Community preparedness and their experience with the response system for dam disaster evacuation may ensure higher possibilities for effective evacuation and minimising life loss. Thus, the community must prepare before the dam failure occurs.

\section{ReSEARCH MeThOdOLOGY}

This study is exploratory research. According to E. Babbie [33], exploratory research acquires knowledge to solve practical problems. Exploratory research helps to determine the community's preparedness for disaster risk reduction in this study. The research employed quantitative methods in eliciting the data. The questionnaire surveys are used as the medium in collecting the data. In this study, two dams in Cameron Highland have been selected for the study areas: Sultan Abu Bakar (SAB) Hydroelectric Scheme and its vicinity in Lembah Bertam; and Susu Dam and its vicinity in Pos Telanok. According to M. Rahsidi et al., [26], the sites have experienced dam spillage incidents in 2013 and 2014, whereby that community was directly severely affected. The site has been selected as the study area due to: i) The selected site is a disaster-prone area and located just downstream of the dams; ii) Site study was densely populated, and they are under the risk and, iii) This vulnerable community has experienced a catastrophic event due to a dam related disaster, which allows them to respond and give feedback on their experience regarding the event.
Based on Yameni formula [34], it required about 350 respondents for the survey. However, in this research, a total of 847 voluntary respondents have responded to the questionnaires. This sample size has increased the confidence level of the survey. The questionnaire was designed in 3 sections: demographic, community awareness, and community preparedness. An outline of the survey design is as shown in Table I.

TABLE I: OUTLINE OF THE SURVEY

\begin{tabular}{llll}
\hline $\begin{array}{l}\text { Section A: } \\
\text { Demographic } \\
\text { information }\end{array}$ & $\begin{array}{c}\text { Section B: } \\
\text { Community } \\
\text { Awareness }\end{array}$ & $\begin{array}{c}\text { Section C: Community } \\
\text { Preparedness }\end{array}$ \\
\hline - & Gender & $\begin{array}{l}\text { Community's } \\
\text { resilience action }\end{array}$ & $\begin{array}{c}\text { Personal } \\
\text { preparation } \\
\text { Preparedness with } \\
\text { family members }\end{array}$ \\
- & Age & $\begin{array}{l}\text { Warning } \\
\text { information }\end{array}$ & \\
- & Religion & Roles/ & \\
- & Residential area & volunteering & \\
- & Length of stay & & \\
- & Educational level & & \\
- & Housing ownership & & \\
- & & \\
status & Education/occupation & & \\
- & & \\
- & & \\
\hline
\end{tabular}

The data collected were analysed by statistical analysis, using SPSS software Version 25. Statistical tests were used to achieve this study's objective and are elaborated using descriptive analysis to generalise the data. From the statistical test conducted, continuous data were presented in summary averages and percentage analysis.

\section{RESUltS AND Discussion}

The findings obtained from the analysis help give more understanding of the community's awareness and preparedness of dam disaster. Community participation is very important as part of the non-structural mitigation approach. The results are important to comprehend the understanding of community preparedness for disaster risk reduction (DRR) for both dams.

\section{A. Participation in Dam Disaster Preparedness}

Based on the result, $91.4 \%$ of respondents stated that they agreed that it is important for residents to participate in the emergency exercises program. Meanwhile, $84.8 \%$ agreed that they were ready to participate in an emergency exercise program conducted by dam owners and agencies. Furthermore, $75.2 \%$ of respondents admit that they have participated in emergency exercise programs in their area. The results show that respondents who volunteered themselves in such activities in the DRR program are more likely to have a better knowledge of disaster preparedness. Respondent's involvement in activities such as evacuation drills made them aware of the importance of participating in the program to be well prepared and become more resilient. The result is shown in Table II.

A Cross-tabulation test between respondents' responses against their experience with disaster was conducted, as 
shown in Table III. The Chi-square results shows that there are significant relationship (Chi square $=17.084 ; 31.792, d f=$ $4, P=0.000 ; 0.002)$ between respondent's experiences on disaster with willingness to participate in DRR program. The result in Table III shows that the p-values of variables between respondents' experience with disaster against their statement on joining disaster preparedness or emergency exercises (0.000) and their readiness to participate in emergency exercises during real disaster situations (0.002) are less than 0.05 . The results indicate that experience allows people to be more aware of disaster, and they are more responsible towards DRR programs. This finding also concurred by [35], which mentioned that the awareness would increases when a community is provided with sufficient information and knowledge about the disaster.

In addition, the result shows that respondents' experience with disaster influenced them to join and ready to participate in disaster preparedness or emergency exercises. Disaster simulation drills help residents improve their disaster preparedness and reinforce their awareness of the importance of providing self-and mutual support in a disaster. It shows that training experience had influenced individuals to respond to disaster consciously, which will also increase their confidence level to act during an emergency. The results are in line with the study by [36], [37].

TABLE II: RESPONDENTS’ PARTICIPATION WITH DRR PROGRAM EXERCISE

\section{Responses}

Statement

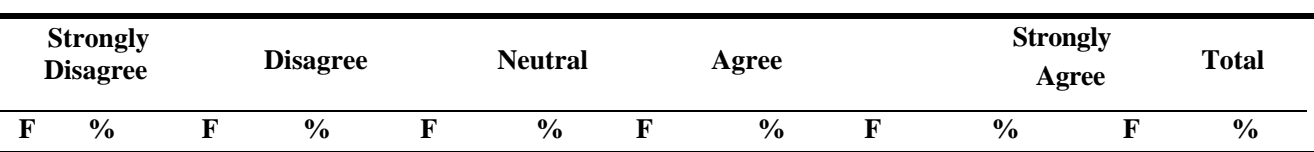

\begin{tabular}{|c|c|c|c|c|c|c|c|c|c|c|c|c|}
\hline $\begin{array}{l}\text { Important for residents to take an } \\
\text { active part in disaster preparedness/ } \\
\text { emergency exercises }\end{array}$ & 3 & 0.4 & 5 & 0.6 & 65 & 7.7 & 353 & 41.7 & 421 & 49.7 & 847 & 100 \\
\hline $\begin{array}{l}\text { I have joined disaster preparedness/ } \\
\text { emergency. } \\
\text { Exercises }\end{array}$ & 74 & 8.7 & 47 & 5.5 & 89 & 10.5 & 223 & 26.3 & 414 & 48.9 & 847 & 100 \\
\hline $\begin{array}{l}\text { Ready to participate in the } \\
\text { emergency exercise program }\end{array}$ & 13 & 1.5 & 20 & 2.4 & 95 & 11.2 & 307 & 36.2 & 412 & 48.6 & 847 & 100 \\
\hline
\end{tabular}

TABLE III: PARTICIPATION WITH DRR PROGRAM EXERCISE AND THEIR DISASTER`S EXPERIENCE

\begin{tabular}{lccc}
\hline & \multicolumn{3}{c}{ Experience with disaster } \\
\cline { 2 - 4 } DRR program/ exercise & Value & p-value & \% count less than 5 \\
\hline I have joined disaster preparedness/ emergency exercises. & 31.792 & 0.000 & 0.0 \\
Ready to participate in the emergency exercise program & 17.084 & 0.002 & 10 \\
\hline
\end{tabular}

Chi square $=17.084 ; 31.792, d f=4, P=0.000 ; 0.002$

Note: For result to be valid, the \% of count less than 5 must be not more than $20 \%$

TABLE IV: CHI-SQUARE TEST BETWEEN RESPONSES ON DRILL EXERCISE PROGRAM AND EXPERIENCE WITH DISASTER

\begin{tabular}{|c|c|c|c|}
\hline \multirow{2}{*}{ Statement } & \multicolumn{3}{|c|}{ Experience with disaster } \\
\hline & Value & P-value & $\%$ count less than 5 \\
\hline $\begin{array}{l}\text { Able to differentiate between drill simulation } \\
\text { and real-life situation }\end{array}$ & 10.951 & 0.027 & 0.0 \\
\hline $\begin{array}{l}\text { Exercise drill is useful in preparing for an } \\
\text { emergency }\end{array}$ & 24.031 & 0.000 & 0.0 \\
\hline Input is given during the exercise drill & 76.854 & 0.000 & 0.0 \\
\hline $\begin{array}{l}\text { Input should be given in small group (1-3 } \\
\text { people) }\end{array}$ & 29.624 & 0.000 & 0.0 \\
\hline $\begin{array}{l}\text { Input should be given in a big group } \\
\text { (>3people) }\end{array}$ & 28.976 & 0.000 & 0.0 \\
\hline $\begin{array}{l}\text { Overall satisfaction with exercise drill } \\
\text { conducted }\end{array}$ & 79.884 & 0.000 & 0.0 \\
\hline
\end{tabular}

Chi square $=10.951-79.884, d f=4, P=0.000-0.027$

Note: For result to be valid, the \% of count less than 5 must be not more than $20 \%$

TABLE V: RESPONSES ON DRILL EXERCISE AND INFORMATION ARE GIVEN WITH GENDER AND MARITAL STATUS

\begin{tabular}{lccccccc}
\hline & \multicolumn{9}{c}{ Gender } & & \multicolumn{2}{c}{ Marital status } \\
\cline { 2 - 7 } Statement & Value & p-value & df & $\begin{array}{c}\text { \% count less } \\
\text { than 5 }\end{array}$ & Value & $\begin{array}{c}\text { \% count less } \\
\text { than 5 }\end{array}$ \\
\hline $\begin{array}{l}\text { Exercise drill is useful in } \\
\text { preparing for an emergency } \\
\begin{array}{l}\text { Input given during the } \\
\text { exercise drill }\end{array}\end{array}$ & 4.834 & 0.305 & 4 & 0.0 & 22.150 & 0.005 & 8 \\
$\begin{array}{l}\text { Input should be given in small } \\
\text { group (1-3 people) }\end{array}$ & 12.672 & 0.013 & 4 & 0.0 & 14.529 & 0.069 & 8 \\
\hline
\end{tabular}

Chi square $=12.672-22.150 ; \mathrm{df}=4,8 ; \mathrm{P}=0.000-0.005$

Note: For result to be valid, the $\%$ of count less than 5 must be not more than $20 \%$ 


\section{B. Preparedness towards Dam Disaster}

According to [38], demographic factors influenced participation and preparedness towards disasters. Female tend to be more concerned about the programs and activities conducted for DRR. However, male is more focusing on the safety of their families and friends.

Therefore, another Cross-tabulation test was conducted to explore the factors that may influence the respondent's responses to the drill exercise program and the respondent's acceptance of the information given. Among the tested factors are the respondent's experiences, gender, and marital status. The Chi-square results shows there are significant influence $($ Chi square $=10.951-79.884, d f=4, P=$ 0.000-0.027) between respondent's responses on drill exercise program and experience with disaster in Table IV, and between responses on drill exercise program and information given with gender and marital status also revealed significant relationship (Chi square= 12.672-22.150; $d f=4,8 ; P=0.000-0.005)$ in Table $\mathrm{V}$. The results indicate that all the factors that have been tested with responses to drill exercises conducted are significantly related.

The overall results indicate that respondents who experience a disaster strike are aware and exposed to disaster knowledge, which reduces the vulnerability towards any disasters that occur in Cameron Highlands, which is also agreed by S. Sadeka et al., [19] and M. L. Zemesa et al., [39]. Furthermore, the study indicates that the respondents be able to make an independent decision since the DRR program in Cameron highlands is conducted. This shows that dam owners and local agencies had succeeded in delivering disaster-related knowledge and early warning information to enhance the community's disaster knowledge and response. The knowledge transfer program needs to be continuously conducted in Cameron highland through a community-based program to ensure the sustainability of the preparedness among the community. Furthermore, mapping analyses would help local authorities and emergency responders develop warning and evacuation plans to rescue people if the dam failure is imminent.

\section{CONCLUSION}

Dam-related disaster is an important issue that needs to be concerned as it impacted the risk community. In the current state, dam owners and respected agencies have been following the roles as stipulated in Directive No. 20, National Security Council (NSC), and Dam safety guideline manual in managing Dam-related disaster (MyDAMS). However, it is crucial to improve community awareness and participation to ensure that the locals are resilient to disaster risk. Respondents' experience with disaster, gender, and marital status influenced their understanding of the risk of dam disaster in their area, and they felt satisfied with the drill exercises conducted. Therefore, people's experience and demographic status should be considered when dealing with an affected community in planning, designing, strategising, and implementing the DRR program related to local disaster management. In order to increase awareness, knowledge is an essential element that needs to be improved and updated regularly and consistently. On the other hand, community involvement and participation in supporting dam owners and agencies in the community-based program is significant. It can be concluded that preparedness is essential to avoid loss of life during a disaster. Therefore, it is important to make the community prepared in facing any possibility of disaster. The community-based program was conducted to prepare the community by raising their knowledge and awareness. The finding indicates that an integrated community-based program is an effective approach to increase people's preparedness for the disaster. It is necessary to recognise that people with different backgrounds and experiences have different preparedness levels for disaster. The result can assist local agencies and dam owners in formulating strategies for future DRR programs. However, in this research, specific state policies associated with DRM are the limitation. Many factors were discovered while assessing the community's preparedness towards dam-related disaster, impelling the community's awareness towards dam-related disaster as throughout this research. Community participation and involvement in the DRR program, such as awareness program and evacuation drill exercise are significant in developing better community resilience to face dam disaster. Thus, integrated involvement of multi agencies and non-governmental organisations (NGOs) is another binding domain to further research to expand knowledge and understand dam-related disaster.

\section{CONFLICT OF INTEREST}

The authors have no conflicts of interest to declare. All co-authors have seen and agree with the contents of the manuscript and there is no financial interest to report. We certify that the submission is original work and is not under review at any other publication.

\section{AUTHOR CONTRIBUTIONS}

Rahsidi Sabri Muda as part of the research team has done the write up of for the literature and analysing data; Mohd Ramzi Mohd Hussain as part of the research team has done the write up for data interpretation; Izawati Tukiman as part of the research team has written the data interpretation and conclusion of the paper, and she is the corresponding author for this paper, and Fatin Shahira Abdullah has written the literature review; all authors have approved the final version of this paper.

\section{ACKNOWLEDGEMENT}

This research was funded by Tenaga Nasional Berhad (TNB), and it was a collaboration between TNB sub-subsidiaries, TNB Research Sdn. Bhd. and International Islamic University Malaysia (IIUM). Authors would like to forward their acknowledgement to TNB Research Sdn. Bhd. and IIUM for this research collaboration.

\section{REFERENCES}

[1] R. Das, "Disaster preparedness for better response: Logistics perspectives," Int. J. Disaster Risk Reduct., vol. 31, pp. 153-159, 2018

[2] R. Muda et al., "Building capacity through school based engagement on dam safety program in cameron highlands," in Proc. 1st Int. Conf. Dam Saf. Manag. Eng. Resour. Dev. Manag., pp. 51-63, 2020. 
[3] C. Guo, T. Sim, and H. C. Ho, "Impact of information seeking, disaster preparedness and typhoon emergency response on perceived community resilience in Hong Kong," Int. J. Disaster Risk Reduct., vol. 50, p. 101744,2020

[4] M. R. Sabri, T. Izawati, A. S. Azila, M. A. Mohamad Faiq, and M. Ainul Bahiah, "Community preparedness for disaster risk reduction from Islamic,” South East Asia J. Contemp. Business, Econ. Law, vol. 20, no. 6, pp. 71-76, 2019.

[5] W. Adiyoso and H. Kanegae, "The preliminary study of the role of islamic teaching in the disaster risk reduction (a qualitative case study of Banda Aceh, Indonesia)," Procedia Environ. Sci., vol. 17, pp. 918-927, 2013.

[6] K. M. MacQueen et al., "What is community? An evidence-based definition for participatory public health," Am. J. Public Health, 2001.

[7] S. M. Hosseini, M. Bahadori, M. Raadabadi, and R. Ravangard, "Ranking hospitals based on the disasters preparedness using the TOPSIS technique in Western Iran," Hosp. Top., vol. 97, no. 1, pp. 23-31, 2019.

[8] D. Kyne et al., "Empirical evaluation of disaster preparedness for hurricanes in the Rio Grande Valley," Prog. Disaster Sci., vol. 5, p. $100061,2020$.

[9] M. K. Lindell and R. W. Perry, "Emergency planning: Improve community preparedness with these basic steps," Emergency Management: Principles and Practice for Local Government, 2008.

[10] N. B. Said and V. C. L. Chiang, "The knowledge, skill competencies, and psychological preparedness of nurses for disasters: A systematic review," International Emergency Nursing. 2020.

[11] UNISDR, "Man-made and Technological Hazards; Words into Action Guidelines,"p. 84, 2018.

[12] UNISDR, "Terminology on disaster risk reduction," Geneva, Switzerland, 2009.

[13] D. A. McEntire and A. Myers, "Preparing communities for disasters: Issues and processes for government readiness," Disaster Prev. Manag. An Int. J., vol. 13, no. 2, pp. 140-152, 2004.

[14] K. Johnson, "SAMHSA disaster technical assistance center supplemental research bulletin greater impact: how disasters affect people of low socioeconomic status," Phys. Heal. Heal. Probl., no. July, 2017.

[15] C. D. V. De Goyet, R. Z. Marti, and C. Osorio, "Chapter 61. Natural disaster mitigation and relief," Dis. Control Priorities Dev. Ctries, vol. 000, no. Ifrc, pp. 1147-1162, 2006.

[16] J. Sutton and K. Tierney, "Disaster preparedness : Concepts, guidance, and research Jeannette Sutton and Kathleen Tierney natural hazards Center Institute of behavioral science University of Colorado Boulder, CO," Disaster Prep., no. March, p. 44, 2006.

[17] R. Patrisina, F. Emetia, N. Sirivongpaisal, S. Suthummanon, A. Alfadhlani, and D. Fatrias, "Key performance indicators of disaster preparedness: A case study of a tsunami disaster," MATEC Web Conf., vol. 229, 2018

[18] Y. Helmi and Hermansah, Redefining Diversity \& Dynamics of Natural Resources Management in Asia: Hydrologic Characteristics, Flood Occurrence, and Community Preparedness in Coping With Floods at Air Dingin Watershed, Padang, West Sumatra, vol. 4. Padang, Indonesia: Elsevier Inc., 2017.

[19] S. Sadeka, M. S. Mohamad, and M. S. K. Sarkar, "Disaster experiences and preparedness of the Orang Asli Families in Tasik Chini of Malaysia: A conceptual framework towards building disaster resilient community," Prog. Disaster Sci., vol. 6, p. 100070, 2020.

[20] A. Chang-richards, K. Fredrick, T. Lindstrom, and J. Richards, "Measuring disaster preparedness of Auckland inner city apartment residents," no. January, 2016.

[21] D. A. Alexander and S. Klein, "First responders after disasters: A review of stress reactions, at-risk, vulnerability, and resilience factors,' Prehospital and Disaster Medicine, 2009.

[22] A. D. Setyawati, Y. Y. Lu, C. Y. Liu, and S. Y. Liang, "Disaster knowledge, skills, and preparedness among nurses in Bengkulu, Indonesia: A descriptive correlational survey study," J. Emerg. Nurs., vol. 46, no. 5, pp. 633-641, 2020.

[23] K. A. Hosseini and Y. O. Izadkhah, "From 'earthquake and safety' school drills to 'safe school-resilient communities': A continuous attempt for promoting community-based disaster risk management in Iran," Int. J. Disaster Risk Reduct., vol. 45, no. January, p. 101512, 2020.

[24] FEMA, "Federal guidelines for dam safety- hazard potential classification system for dams," U.S. Federal Emergency Management Agency, 2004.
[25] Y. Luo, L. Chen, M. Xu, and X. Tong, "Review of dam-break research of earth-rock dam combining with dam safety management," Procedia Eng., vol. 28, no. 2011, pp. 382-388, 2012.

[26] M. Rahsidi, Sabr, T. Izawati, M. H. Mohd Ramzi, and Z. Ismawi, "Perception analysis on public awareness and preparedness towards Early Warning System (EWS) for dam safety: A case study in Bertam Valley Cameron Highlands," Int. J. Hydropower Dam, vol. 24, no. 5, pp. 9-11, 2017.

[27] D. M. McClelland and D. S. Bowles, "Estimating life loss for dam safety and risk assessment: Lessons from case histories," Dam O\&M Issues - Chall. 21st Century, 2000.

[28] E. Fish, "The forgotten legacy of the banqiao dam collapse.," The Economic Observer, pp. 2-4, 2013

[29] Mike Ives, "A day before laos dam failed, builders saw trouble," The New York Times, Attapeu Town, Laos, p. 1, 2018.

[30] S. Bahri, "Ringlet dam disaster: Death and destruction on highlands," The Star, Kuala Lumpur, 24-Oct-2013.

[31] M. S. Khalid et al., "Failure to react positively to flood early warning systems: Lessons learned by flood victims from flash flood disasters: The Malaysia experience," Int. Sch. Sci. Res. Innov., vol. 9, no. 5, pp. 9-14, 2015.

[32] N. Yahya et al., "Building human resilience: The role of community based training and awareness programme (CBTAP) for dam related flood risk management," ASM Sci. J., vol. 11, no. 3, pp. 201-211, 2018

[33] E. Babbie, The Practice of Sosial Research, Thirteenth, Wadsworth, Canada, 2013.

[34] T. Yamane, Statistics: An Introductory Analysis, 2nd Editio., no. 1. New York: Harper \& Row, New York, Evanston \& London And John Weatherhill, Inc., Tokyo, 1967.

[35] F. Juanita, S. Suratmi, and I. L. Maghfiroh, "The effectiveness of basic training on disaster management pilot program for disaster preparedness in community," Indones. Nurs. J. Educ. Clin., vol. 2, no. 2, p. 126, 2018.

[36] S. N. S. Saibi and W. K. A. W. Mokhtar, "Conventional disaster management: Issues and challenges towards Muslims," Int. J. Acad. Res. Bus. Soc. Sci., vol. 7, no. 5, pp. 400-411, 2017.

[37] R. S. Muda, I. Tukiman, A. A. Sarkawi, M. F. M. Amin, and A. B. M. Khidzir, "Community preparedness for disaster risk reduction from Islamic perspectives in promoting DAM disaster management," South East Asia J. Contemp. Business, Econ. Law, vol. 20, no. 6, pp. 71-76, 2019.

[38] K. Cui, Z. Han, and D. Wang, "Resilience of an earthquake-stricken rural community in southwest china: Correlation with disaster risk reduction efforts," Int. J. Environ. Res. Public Health, vol. 15, no. 3 , 2018

[39] M. L. Zemesa and D. B. Hess, "Effects of public perception on urban planning: Evolution of an inclusive planning system during crises in Latvia," Town Plan. Rev., vol. 87, no. 1, pp. 71-92, 2016.

Copyright (C) 2021 by the authors. This is an open access article distributed under the Creative Commons Attribution License which permits unrestricted use, distribution, and reproduction in any medium, provided the original work is properly cited ( $\underline{\mathrm{CC} B Y} 4.0$ ).

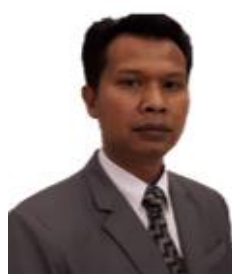

Rahsidi Sabri Muda holds degrees in the MSc civil (The University of Sheffield, UK), the MSc Bldg. Tech (USM, Malaysia), the BEng Civil (UTM, Malaysia), the BSc BE (USM, Malaysia), Dip Civi Engineering (UTM, Malaysia), and he is currently doing his $\mathrm{PhD}$ in disaster risk management at International Islamic University Malaysia. He is also a professional member of the Malaysia Board of Technologist (MBOT).

He is a principal researcher in TNB Research Sdn. Bhd. He has published various article related to his area of expertise, such as Dam-related Disaster Risk Reduction: A Multi-Sectoral Approach as Responsibilities in Building Resilient Society (Johor, Malaysia: UTM PRESS, 2020). Dam Break Flood Mapping Analysis and Impact Assessment (Bingley, UK: Emerald publisher, 2020), and Knowledge transfer in people-centred dam-related disaster program in Cameron Highlands (Kuala Lumpur, Malaysia: Proceeding IOP Conference Series: Materials Science and Engineering, 2020). His expertise is in dam safety and management.

Mr Rahsidi has actively involved in MyCOLD (Malaysia) as Chairman Sub-committee on public safety around the dam, and Science Technology Expert Panel (STEP) as sub-committee members for Emerging risk, Malaysia. 


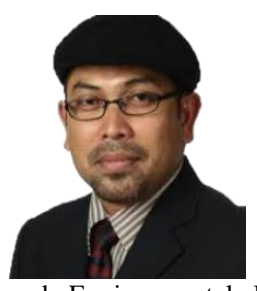

Mohd Ramzi Mohd Hussain is graduated from (UTM, Malaysia), M.A. (Oxford Brookes, UK), BLArc (UTM, Malaysia), Dip. Arch. (UTM, Malaysia), Corporate Member of Institute of Landscape Architects Malaysia (ILAM), senior lecture at IIUM.

$\mathrm{He}$ is an associate professor at the Department of Landscape Architecture, Kulliyyah of Architecture and Environmental Design (KAED), International Islamic University Malaysia (IIUM). He is also currently holding the position as a director, Occupational Safety, Health and Built Environment (OSHBE), Office of Executive Director, Development \& Planning Division, IIUM. He had registered as the corporate members of the Institute of Landscape Architects Malaysia (ILAM) and was appointed as the Council Members (2014/2016; 2016-2018; 2018-2020). He has worked as a Landscape Architect in private practice in Malaysia and Singapore prior to joining the IIUM in May 1999. $\mathrm{He}$ has authored and co-authored papers for the indexed and non-indexed journal; edited, internal reviewers and external assessors for books, papers and thesis on landscape architecture, urban design, GIS, IT, urban planning and architecture.

Dr Mohd Ramzi is active in research, postgraduate supervision and consultancy. In the aspect of consultancy, he has involved in many landscape master planning, design and research project such as preparing the Landscape Master plan for the Proposed Master Plan for the International Islamic University of Afghanistan (IIUA), Kandahar, Afghanistan (Physical Group). His research interest includes sustainable environment an environmental modelling, urban landscape design, residential and universal landscape design, cultural landscape and GIS management and landscape planning (tourism planning).

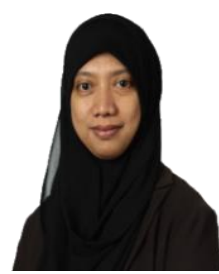

Izawati Tukiman got the $\mathrm{PhD}$ sustainable landscape (The University of Sheffield, UK), the MSC landscape architecture (USM, Malaysia), the BSc housing, building and planning (architecture) (USM Malaysia), the Dip. architecture (UTM, Malaysia), professional member of Malaysia Board of Technologist (MBOT), an associate member of Institute of Landscape Architects Malaysia (ILAM). She is a senior lecturer at Kulliyyah of Architecture and Environmental Design (KAED), IIUM, Malaysia, and a qualified access auditor for Universal Design in the built environment. She has published various article related to her area of expertise, such as Dam related disaster framework for emergency preparedness (Kuala Lumpur, Malaysia: Planning Malaysia: Journal of the Malaysian Institute of Planners, 2020), Safe heavens and evacuation routes due to dam disaster (Bhopal, India: International Journal of Recent Technology and Engineering (IJRTE), 2019), .and An assessment on early warning system: Initial survey analysis (Kuala Lumpur, Malaysia: Planning Malaysia: Journal of the Malaysian Institute of Planners, 2019)

Dr Izawati is also actively involved with the society through professional consultancy activities, especially on universal design and community-based disaster (CBDR) programs. Other than that, she has also contributed her expertise with other organisations such as Public Work Department (JKR), Malaysia, by providing training and facilitating on universal design and river management (disaster risk and management)

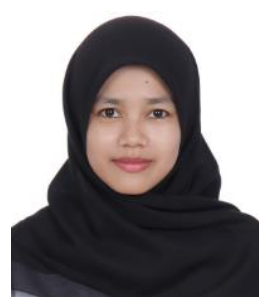

Fatin Shahira Abdullah holds the BEng Civil (UNITEN, Malaysia). She is currently a research engineer at TNB Research Sdn. Bhd. Her interest is in disaster risk management (DRM). 